Chapman University

Chapman University Digital Commons

Education Faculty Articles and Research

College of Educational Studies

$12-29-2015$

\title{
'Tell Your Own Story': Manhood, Masculinity and Racial Socialization Among Black Fathers and Their Sons
}

Quaylan Allen

Chapman University, qallen@chapman.edu

Follow this and additional works at: http://digitalcommons.chapman.edu/education_articles

Part of the African American Studies Commons, Educational Sociology Commons, Family, Life Course, and Society Commons, Gender and Sexuality Commons, Other American Studies $\underline{\text { Commons, Other Education Commons, Race and Ethnicity Commons, and the Social and }}$ Philosophical Foundations of Education Commons

\section{Recommended Citation}

Allen, Q. (2016). "Tell your own story": Manhood, masculinity and racial socialization among black fathers and their sons. Ethnic and Racial Studies, 39(10), 1831-1848. doi: 10.1080/01419870.2015.1110608

This Article is brought to you for free and open access by the College of Educational Studies at Chapman University Digital Commons. It has been accepted for inclusion in Education Faculty Articles and Research by an authorized administrator of Chapman University Digital Commons. For more

information, please contact laughtin@chapman.edu. 


\section{'Tell Your Own Story': Manhood, Masculinity and Racial Socialization Among Black Fathers and Their Sons}

\section{Comments}

This is an Accepted Manuscript of an article published in Ethnic and Racial Studies, volume 39, issue 10, in 2016, available online: $\mathrm{http}: / /$ www.tandfonline.com/doi/abs/10.1080/01419870.2015.1110608. It may differ slightly from the final version of record.

\section{Copyright}

Taylor \& Francis 


\title{
"Tell your own story": Manhood, masculinity and racial socialization among black fathers and their sons
}

\begin{abstract}
This study examines how black fathers and sons in the U.S. conceptualize manhood and masculinity and the racial socializing practices of black men. Drawing upon data from an ethnography on Black male schooling, this paper uses the interviews with fathers and sons to explore how race and gender intersect in how Black males make meaning of their gendered performances. Common notions of manhood are articulated including independence, responsibility and providership. However, race and gender intersect in particular ways for black men. The fathers engaged in particular racial socializing practices preparing their sons for encounters with racism. Both fathers and sons adopted black existentialist perspectives, emphasizing self-determination and resilience as racially and politically motivated acts of resistance. Finally, the paper describes how the fathers modeled to their sons how to navigate racialized spaces as black men.
\end{abstract}

Keywords: black males, black fathers, manhood, masculinity, racial socialization 


\section{Introduction}

Research on the role performances of American black men has examined black male responses to an array of structural barriers. In the labor market, black men are least likely to be hired, first to be laid off, and experience high unemployment rates (Hoffman, Llagas, and Snyder 2003; Wilkinson 1999; U.S. Department of Labor 2013). They experience vast income and wealth inequalities compared to their white male counterparts regardless of class standing (Hoffman, Llagas, and Snyder 2003; Wheary et al. 2008). Furthermore, black men are treated exceedingly different in the judicial system where they are arrested and convicted at higher rates (Mauer 1999; U.S. Department of Justice 2012), and experience harsher sentences than white males for the same offense (Mustard 2001).

Black male responses or cultural adaptions to these conditions, such as seeking employment in underground market economies or performing hypermasculinities as a practice of compensatory subordination (Harris 2000), has led some to proclaim a 'black male crisis'. This 'crisis' presumes that black male psychology, behavioral performances and conceptions of manhood are emblematic of cultural pathology (Staples 1982; Mauer 1999; Frazier 1966). The Moynihan Report (1965) in particular, argued that structural factors such as black male unemployment, contributed to the rise of absentee fathers, single mother and female headed households, reproduction of ghetto pathologies and the overall demise of the black family. Consequently, the absence of black men in the home was considered an impediment to appropriate black male socialization, and young boys 
were assumed to grow up without adequate models of manhood (Staples 1982; Pleck 1981).

The dilemma with these perspectives on black manhood is that, while they recognize structural barriers as well as the corresponding cultural adaptions of black men, they still measure black male practices against white hegemonic masculinity. In other words, whether responding to structural impediments or due to their own pathology, black men are perpetually seen as falling short of dominant conceptions of masculinity. This perspective fails to recognize how black men learn and conceptualize manhood and masculinity in ways that contest or accommodate dominant gender expectations. Black men are often the "hidden voices" in discourses regarding them (Hunter and Davis 1994). To this end, this paper describes how black residential fathers and their sons make meaning of their conceptions of manhood and masculine influences. Additionally, the paper examines the way black fathers socialize their sons by explaining endemic racism, emphasizing Black male agency, and modeling for their sons how to manage race in space.

\section{Masculinity, manhood and black fathers}

In decoupling gender definitions from biological explanations, poststructuralist gender scholars argue that gender is a socially constructed system of symbolic practices and performances and is constantly informed by and through relationships of power (Butler 1993; Gardiner 2005). In other words, being male or female is a biological distinction whereas gender is what people do and how they interpret what they do (Holter 2005). Within the structure of gender are configurations of practice, which produces 
masculinities and femininities. These gender practices may shift over time, between contexts and reflect proximity to power (Brittan 1989).

Masculinities are learned and practiced within the spaces of schools, workplaces, sports, communities and the home among other sites (Anderson 2002; Mac an Ghaill 1994; Gutmann 1997). Through self-regulation men demonstrate adaptivity or resistance to dominant or subcultural definitions of masculinity, enacting the "correct" masculine performance at the right time and place (Whitehead and Barrett 2001).

For black men existing in a society in which racism is endemic, race and gender intersect in particular ways (Crenshaw et al. 1995). Black men are both idolized and feared, and as the hyper-visible racialized 'other', their masculine performances are disproportionally surveilled and regulated. Considering the role race plays in the regulation of black behaviors, black masculinities then might be understood as a collection of practices performed within racialized discursive processes of black subjugation and exploitation (Marriott 1996; Hall et al. 1978). However, despite the racialized context in which black men perform gender, black male performances, like other masculinities, are diverse, complex and performed differently over time and space.

In moving between various ideological settings men also learn about the ontologies of manhood, or what it means to be a man (Hunter and Davis 1992; Dancy II 2012). Their masculine practices emerge from these ideals. For instance, economic provider, family responsibility, or protector may be manhood ideals that guide masculine practices (e.g. working, fatherhood). In many ways, black men conceptualize manhood consistent with dominant male culture, but in other ways their understandings are nuanced through the intersectionality of their raced and gendered lives. Hunter and Davis 
(1992) examined black men's conceptions of manhood and argued, "Black men are expected to conform to dominant gender role expectations (e.g. to be successful, competitive, aggressive), as well as meeting culturally specific requirements (e.g. cooperation, promotion of group, and survival of group) of the Black community, which often conflict" (p. 24). In other words, the standpoint of black men might produce varying and complex understandings of manhood and performances of masculinity.

Fatherhood is one of many masculine performances for black men, though much of the research literature on fatherhood generally characterizes black fathers as nonresidential, absent and uninvolved (Johnson Jr. 2001; Hamer 1997; Chien-Chung Huang 2002; Moynihan 1965). Roughly 70 per cent of black children are born to unwed parents and most will live apart from their biological father (Shattuck and Kreider 2013). Black boys who grow up without a residential and/or involved father are at higher risk of criminal or violent activities, poorer school outcomes, substance abuse and lower psychological functioning (Dubowitz et al. 2001; Pan and Farrel 2006; Caldwell et al. 2004).

Structural factors must also be considered, including how income inequality and incarceration might influence family structures and the involvement practices of black fathers (Anderson 1990; Clayton and Moore 2003; Edin and Nelson 2013). For example, high unemployment and incarceration rates of black men might limit the ability to provide meaningful financial support and meet particular normative expectations of manhood. Without considering the effect of structural barriers, much of the literature on black fatherhood tends to pathologize the black family as dysfunctional and black men as "deadbeat dads." 
Despite the prevalence of deficit discourses about black fathers, there are many residential and nonresidential fathers who are involved in their children's lives. Studies highlight how black fathers provide, nurture and act as playmate for their children (McLoyd, Cauce, and Takeuchi 2000; Coles 2001). Black fathers' school involvement practices, including their high academic expectations, academic support and teacher relationships have also been documented (Hrabowski III, Maton, and Greif 1998; Grantham and Henfield 2011). Finally, black fathers engage in positive racial socializing practices, sending their children messages of racial pride, preparing them to navigate potential racial barriers, and emphasizing racial resiliency and self-determination (Mandara 2006; Greif, Hrabowski, and Maton 1998). These types of paternal involvement practices are associated with increased academic and professional achievement, decreased delinquency, and overall well-being of black children (Caldwell et al. 2004; Dubowitz et al. 2001; Hebert, Pagnani, and Hammond 2009).

In summary, the family arrangements and involvement practices of black men are diverse and complex, though there is still little qualitative research on residential black fathers and their racial and gender socialization practices. Moreover, there is little to no research examining black male conceptions of manhood and masculinity from the multivocal perspective of both fathers and their sons. Finally, this study contributes to an emerging body of literature examining the assets of black fathers, including their parental involvement practices. 


\section{Methods}

\section{Participants}

The findings presented in this paper derive from a larger ethnographic study examining the schooling experiences of black male middle and working-class youth and their families. The study sample, drawn through purposive and snowball sampling methods (Goetz and LeCompte 1984), included ten black families sending their sons to a racially integrated high school in a large U.S. west coast metropolis. Six of the families consisted of residential fathers who were involved in their son's life. No residential fathers were present in the homes of the remaining four. The current study focuses on the six families with residential fathers. These fathers were married, heterosexual and relatively middle-class based on common sociological indicators of social position among black families (Pattillo-McCoy 1999; Collins 1983; Ginwright 2002). Most were college educated, occupied white-collar or high paying blue-collar jobs, owned their home, and contributed to family income exceeding the poverty threshold by over 300 per cent, placing them within a middle-income bracket (Bureau 2008). In addition, none of the children of the middle-class families qualified for free or reduced lunch.

Though these fathers might be generally considered middle-class, they come from working-class backgrounds, and were the first in their families to experience some form of upward mobility. Thus, it must be made clear that what is presented in this paper, which is black heterosexual fathers conceptions of manhood, masculinity and socialization practices, is not meant to be representative of black middle-class families. 
Indeed, many black fathers regardless of class position and sexuality might conceive of manhood, perform masculinity and socialize their sons in ways similar to the men highlighted in the current study.

\section{[Insert Table 1 about here]}

\section{Data collection and analysis}

Document collection, field observations, semi-structured and unstructured qualitative interviews were used in the collection of data for the larger school ethnography . The data presented in this paper largely comes from the qualitative interviews, as I am interested in the interpretive standpoint of the fathers and sons. The students participated in two in-depth semi-structured interviews and one photo elicitation interview. One of the semi-structured interviews focused specifically on race, manhood and masculinity. The parents were each formally interviewed once regarding the educational experiences of their sons and their conceptions of race, manhood and masculinity. Taken together, the interviews became multivocal interpretations on the same phenomenon, and were an important source for discovering meaning behind the actions and behaviors of participants. All interviews were recorded with a digital recorder and later transcribed.

Triangulation of analysis was built into the data collection process as multiple data sources (e.g. interviews, observations, document collection, etc.) were used to confirm or disconfirm any findings (Huberman and Miles 1994). Data analysis itself followed a qualitative interpretive approach referred to by Erickson (1986) as "modified analytic induction". Interviews and field notes were transcribed and the data corpus was 
read thoroughly and repeatedly to get a holistic sense of the phenomena, and Atlas.ti qualitative research software was used for coding and managing the data corpus.

\section{What does it mean to be a man?: Black manhood, masculinities and role models}

During interviews with the sons and fathers, they were asked to provide their definitions of manhood. Consistent with others studies examining black manhood (Hunter and Davis 1992, 1994; Dancy II 2012), the men generated comments related to responsibility, independence, being a provider and a spiritual leader for one's family. For example, Mr. Baker, the father of Jamaal, describes manhood as "being able to take responsibility. Being responsible for your actions and what you do". Similarly, Mr. Anderson, the father of Billy, provides his definition:

I would define it in one word: responsibility. Because responsibility covers the whole. When you're responsible, you're going to take care of your wife. When you're responsible you're going to take care of your kids. When you're responsible you're going to take care of the bills. When you're responsible you're going to take care of the household. When you're responsible you're going to make sure that the plumbing is working, the cars are washed, the oil is changed. Responsibility covers the whole gambit as far as all those things...

For the sons, independence was a precursor to demonstrating responsibility in that taking care of yourself allowed you to be responsible to others. Sean, the son of Mr. Strauss articulates manhood as "any man who can take care of himself first of all and take care of his family and just really provide for himself and his family." 
As evidenced by Sean's statement, the men in this study saw providership as an important quality of manhood, using phrases like "being a provider for your family" or "taking care of your own". These qualities of manhood were closely tied to their religious beliefs, particularly for the fathers. Each of the fathers considered themselves religious, five of which were heavily involved in their churches with two of the fathers serving as church elders. For the fathers, their notions of manhood were closely tied to their religious beliefs, where manhood was considered a "God-given responsibility". Many of the fathers referred to themselves as the "priest of the household". Mr. Howard, the father of Rodney, best draws the connection between his religious beliefs and the role of men in the family:

I think in God's design for manhood, he established some principles that men should convey to their family. We should be the kings of our home. And kings not so much that we are a dictator [or] ruler, but a king in ancient times was responsible for the safety of the kingdom and provision and so men should make the home safe and he should be a provider. He should be a priest to the home. He's responsible for the spiritual vitality of the home by precept and example.

The sons and fathers idealized manhood as one of responsibility, independence, providership and religious duty, however manhood like any practice of gender socialization is a learned process (Bandura and Walters 1963; Connell 1995). The interviews revealed how and where the men drew upon various models of masculinity to construct their own view of manhood. 
When discussing what models of masculinity were most prevalent in their lives, the fathers and sons provided examples that reflected their particular relational proximities to other men. For the fathers, five of the six grew up without their biological father present in their lives. Most were raised in single parent households. Thus when asked about the prevalent men in their lives, the fathers responded by sharing the challenges of being raised without a father in the home. Mr. Anderson speaks to his own experience being raised by a single mother:

Nobody really taught me how to be a man and so for years I was going along saying, "I know what it is to be a man", but really I didn't because I didn't have an example to follow. There was nobody there to say, "Hey, this is what being a man is."

Other fathers echoed this sentiment about the challenges of not having models of masculinity in close proximity to them. In very few cases did the fathers identify a local community member or relative as a role model, though popular black male figures such as Martin Luther King, Jr. and Marcus Garvey were regularly identified as male role models from their youth. Even though the fathers in the study lacked male figures in their homes, it is evident that 1) their mothers were capable of raising black boys, and 2) they were capable of identifying positive but predominantly heterosexual models of masculinity in other social contexts though the consistency and proximity of these relationships appears tenuous.

Consequently, it appears that the lack of male role model in the home was an impetus for how involved these fathers were in their own son's lives. The sons in the 
study overwhelming identified their father as their greatest model of manhood. Sean explains that his dad, Mr. Strauss, teaches "me things that I need to know in order to survive." And though the sons identified other positive and habituated images of black masculinity such as Barack Obama (Fiske et al. 2009), they recognized the relational proximity to their fathers as influential. Billy best describes his father, Mr. Anderson's influence saying,

I think my dad, that's the only person. Because you hear about Barack Obama and all the other men and it's good to think about them but you're not around them. Some of the things they do may affect you but I think of my dad because a lot of the stuff that he does rubs off on me, and that's the most immediate person who I can follow...that's just the person I'm around.

The sons described their fathers as role models and mentors who provided necessary advice, even when they didn't want to hear it. For example, Rodney, the son of Mr. Howard explains how his dad "talks my head off...but it is good advice, but I mean I hate hearing it. I know deep down he's right." Similarly, Jayson explains his relationship with his father, Mr. Mensah explaining, "I can talk to him about anything. He can talk to me about anything. He keep it real."

Considering the male participants' relationships with their fathers, it is unsurprising that they attribute some of the perceived difficulties of black male identity development to fatherless black homes. Similar to Mr. Anderson's earlier reflection on growing up in a single parent homes, Mr. Howard's narrative best represents the fathers' views on the importance of a father in the development of black manhood and heteronormative masculinity: 
I did a presentation years ago for a church and mission project and it was entitled the Black Male Endangered Species and I took some research from the Board of Education, Department of Corrections and took some stats and stuff. The one thing I found was very odd. In the early 60 s, 70 per cent of black families had a male in the home. In a 30 year period, that stat had reversed and so you had 70 per cent out of the home and mostly the homes were run by females... and I think that impacts the black male. I think it impacts the fact that there's no modeling going on in the black community. So now we don't have the accountability. If you ask young black men today if they didn't have a father at home, "Who do you model after?" It's going to be an athlete, it's going to be a rap person, which they really have no personal connection to. They don't even know this person's lifestyle. They have nothing else to draw from and so it's a void there that has to be filled. Mr. Howard is correct in his explanation of the changes in black family structures (Taylor 2002), though like the other fathers, he fails to account for structural changes in employment, incarceration rates, and institutionalized racism that may impact the organization of black families (Anderson 1990; Clayton and Moore 2003). It's also notable that while the fathers emphasized the importance of residential male figures as role models, they did so without conflating residence with marriage despite their own involvement in heterosexual marriages. Moreover, though the fathers also came from homes without a residential father, as children born during the black civil rights era, the fathers often identified an array of Black political leaders as models, models they believe have since been replaced with current popular representations of black masculinity in the athlete and rapper. 
The sons and fathers conceptualized manhood in ways consistent with the literature, though how they understood and learned the meaning of manhood came from varied sources. For the fathers, manhood and masculinity was learned through available role models outside the home. For the sons, manhood and masculinity was learned largely through their fathers, who were present in the home and influential in their lives. Consistent with some of the literature on black fathers, the men in this study thus interpreted the lack of male parent role model in the household as a dilemma for black boys (Frazier 1966; Moynihan 1965; Lamb 2004).

\section{Racial socializing practices of black fathers}

The interviews revealed conceptions of manhood and masculinity and how the sons and fathers understood the importance of black fathers as role models. In addition, the interviews provided insight into how the fathers socialized their sons with particular notions of manhood and performances of masculinity. As black men in a racist society, the recognition of racism in a supposed 'post-racial' society required these fathers to engage in proactive socialization practices with their sons. Proactive racial socialization among black parents includes communicating the realities of racism, while teaching cultural pride and providing strategies for overcoming racial barriers (Mandara 2006; Caughy et al. 2002).

\section{Realities of racism}

Both sons and fathers were cognizant of social and institutional racism and shared personal encounters with racism in school settings, work environments, and other social 
settings. For the sons, their encounters with racism largely existed within school spaces, where teachers and school staff assumed they were of low intelligence and inherently deviant. The sons found themselves academically tracked out of upper ability courses by school counselors, racially profiled by school administrators and disproportionally disciplined in accordance to "colorblind" school policies (Author 2013). Many of these experiences were attributed to larger negative perceptions of black males as antiintellectual, hyper-aggressive, deviant and needing to be controlled (Harris 2006; hooks 2003). Thus, despite largely coming from middle-class families and attending a suburban high school, these young men were subject to particular types of racial profiling as black men. For example, Sean explains the dilemmas of pejorative black male stereotypes:

I think as Americans we have this perception of black men. Like, there's a saying that if you want to hide something from a black male, put it in a book. And so I guess we've come to this conclusion that black men aren't smart and you just need to put them in some special ed class...I think some people perceive black men as "oh, we're just going to beat you up", stuff like that. Like all of us are in gangs or all of us smoke or do drugs or stuff like that. All of us are athletic. All of us are pimps. I think that's just based on what you see on TV and that's just how the media has projected us as.

The fathers spoke similarly of their experiences with racism, though as observers of the mid- $20^{\text {th }}$ century U.S. civil rights movements, they were privy to how racism had shifted from overt to covert. For instance, the fathers spoke initially of more explicit forms of racism such as growing up in segregated neighborhoods, attending segregated schools or being denied access to housing because of their race. Mr. Strauss even detailed 
his unfortunate experience of walking out his front door as a child in Oklahoma to observe a friend from his neighborhood who had been hung from a tree. However, as a result of civil rights progress, the economic and social mobility of these black men placed them in more integrated work and neighborhood settings. Thus, they recognized racial progress but also articulated how the nature of racism had changed, becoming more subtle and covert. Instead of experiencing the covert racism of their youth (i.e. segregation), they explained racism as subtly embedded in institutional processes and everyday social interactions.

For example, some of the fathers spoke of being passed over for promotions by less qualified white colleagues. Others spoke of the differential expectations held of black men in the work force. Mr. Mensah describes a series of instances in which racism is subtly encountered:

You go into the store and you buy something and they're following you around and watching you and it keeps on going. You go to a restaurant and you're the last to get waited on and when you do get waited on, it's not what you ordered. And they're sending--sometimes the message is so subtle--they're saying, "We don't want you," and you go through these things all your life. It's like that conversation that's being held. You know, somebody's talking about you and you walk in and they stop talking and you feel it. Now, if you're stupid you're going to say, "Were you guys talking about me?" And they're going to say, "of course not! Why would you think"--you understand what I'm saying? It's like we know it's there, but how do we get to it? And it wears on you... 
The subtle forms of racism presented by both the sons and fathers are referred to as microaggressions (Pierce et al. 1978), which is the covert or subtle racism that often goes unnoticed but quietly demeans and denigrates black men. As Mr. Mensah eludes to at the conclusion of his statement, the cumulative effect of these subtle offenses is fatiguing for black men, leading to what is known as racial battle fatigue (Nunez-Smith et al. 2007; Smith 2004). The effect of these denigrating experiences also perpetuates feelings of inferiority. To proactively combat these racial encounters, the fathers communicated black existential perspectives and emphasized racial resilience as a means to persist through potential racial barriers.

\section{Black existentialism and self-determination as racial resilience}

In general, the fathers were proactive in the racial socialization of their sons teaching messages of self-development. In particular, the men espoused black existentialist perspectives, a school of thought concerned with the embodied agency and liberation of black peoples (Gordon 1997). They believed black men should be responsible for constructing their own identity and should define black masculinity outside of white hegemonic discourse. The fathers wanted their sons to "walk to the beat of a different drummer" and not feel the need to subscribe to negative black male stereotypes. For example, Mr. Strauss teaches his children this form of resistance: And I tell my children, don't let anybody tell who you are. You tell your own story. You can tell it better than anybody. Don't let your attitude reflect what people already think. They're already going to think [certain things] about you. That's not who you are. Tell your own story. 
In a similar fashion, Mr. Baker succinctly explains, “don't be the norm, you know, do you." The sons articulated these existential perspectives, explaining that black people needed to take control of their own existence, or as Sean explains, resist a slave mentality:

It all comes to what I call slave mentality, and so until black people as a whole get rid of this "I can't do it or the man is holding us down," then you won't be able to succeed. You need to set your own goals besides listening to other people and don't let them label you as to what you are. Don't let them put any boundaries on what you can do because you know what you can do and what you can't do. Basically just get rid of this mentality that you're not worth anything.

In particular cases, while espousing existential perspectives, the men downplayed the role of race as a barrier for black people and instead pointed to motivational factors as a disadvantage. Mark explains this belief:

I think it's less people willing to break that statistic. They know that people expect less from them and so they feel that since the standard is less they can do less... and so maybe you're holding yourself down with using race as an excuse. That's a problem.

The men espoused these types of individualistic expectations despite having detailed their own experiences with race as a structural barrier. This is consistent with the empirical evidence on dual consciousness (Welburn and Pittman 2011) that suggests middle-class blacks may believe that both racial barriers and motivational factors are impediments to black advancement. 
While acknowledging race as a structural barrier, the fathers modeled and expected their sons to demonstrate agency in the face of racism. As part of their socializing practices, the fathers promoted the value of self-determination and provided their sons with tactical strategies to navigate black and white worlds. Mr. Strauss emphasizes self-determination as a form of racial resilience by teaching his son how to respond to school racism:

Sean has come home and told me some things. I said, you know, you're going to have to be bigger. Don't allow anybody to hold you back. Get it for yourself. And that's one of the advantages right now that I believe my son and my children have. You don't let anything hold you back.

Jayson echoes this sentiment of self-determination saying, "As a black male...things don't come to us easy. We have to want to get them, we just have to do everything yourself." In addition, because these fathers and sons were aware of the pejorative views of black men, and that they would be held to a different standard than their white counterparts, they engaged in particular destigmatizing practices to dispel racialized myths. Mr. Anderson speaks to the double standard placed on black men stating, "To be black means you have to excel far beyond what everybody else does in order to achieve the same thing." Likewise, Mr. Howard describes his socialization practice regarding preparing his son potential employment discrimination:

You know he will still have to contend with the race issues. You find another avenue to get around it. And so you still have to face it. You still have to be persistent. You still have to make yourself qualified and in some cases more qualified than the next person because it is a competitive environment. And I 
think it's important that you as black men, that you distinguish yourself from the myths.

As a result of these socialization practices, the sons understood that as black males "you have to be twice as better as anybody else because society will try to bring you down." Thus, like Mark, they were racially motivated to dispel myths:

Yeah, like how I was saying, it is harder for black males in high school...all those things that are working against you. Even though they are working against you, you're still trying to reach whatever goal you have. I think that's necessary for a black man today, especially when there's racism. Just get past that, work through it, prove them wrong.

Demonstrating competence and intelligence to dispel racial myths is a destigmatizing practice used by other middle-class blacks (Lamont et al. 2005). However, it seems their self-determination was a racially and politically motivated act of resistance against white hegemony. To achieve advancement in spite of the odds, or to "prove them wrong," appears to be a notable act of moral indignation.

\section{Negotiating racialized spaces}

As I have introduced elsewhere (Author 2013), the expectation of racial resiliency established by their parents was not merely theoretical but was accompanied by particular forms of navigational capital (Yosso 2006), which is the knowledge of how to navigate social spaces and institutions where race may be a barrier. Markedly, the fathers taught their sons how to 'walk in and out of worlds' or become 'cultural straddlers' (Carter 2006), learning how to move between cultures by adopting and performing certain 
masculine behaviors that are deemed appropriate in the given social context. Mr. Howard explains what he teaches his son Rodney about negotiating racialized spaces:

When I was in school, you know, when you had an afro sometimes the afros were intimidating to white people, especially if you were going for an interview. So you find ways to get around that. You cut it. You shrink your fro and you make yourself, you sanitize yourself so you're not a threat. And you know that's not selling out. That's wisdom. Until the person gets to know who you are as a person, they're gauging you based on what they see and what they see is based sometimes on misinformation...so you find ways to go in and out of different worlds and that's an art. That's something that you have to learn.

The sons also grasped this concept of racial 'border crossing' (Delgado-Gaitan and Trueba 1991), articulating how their masculine performances and presentation of self (Goffman 1959) shifted among social contexts. Describing how he moves between black and white worlds, Billy explains:

It depends on how you let yourself come across because I could be nerdy, but I can also be just, be myself too.... Like if I were to go to a job interview, I wouldn't act how I would around my friends. You just need to know how to play [the game]...it's just a form of common sense and intelligence, knowing when things are suitable and when things are not.

Consistent with other studies describing how black families manage racial identity in public and private spaces (Lacy 2007; Rollock et al. 2011), these black men engaged in particular destigmatizing practices they believed would improve their professional and economic opportunities. 
It also appears that their adoption and self-regulation of certain masculine practices within varying racialized spaces is indicative of Dubois' (1903) notion of double-consciousness. They are aware of the larger myths regarding black men, though these myths are not indicative of their reality. To mitigate the discontinuities between perception and reality, they engage in a collection of destigmatizing practices perceived as necessary for professional and economic advancement. In many ways, this ideological standpoint is similar to a black functionalist orientation (Watkins 1993), which necessitates that in order for black men to succeed in the white world, they will need to "play the game" or adopt the rules and masculine performances of the dominant culture without compromising their own cultural identities. Considering the racial socializing practices of the fathers, it would seem that learning to negotiate racialized spaces, or 'walking in and out of worlds', is less about assimilating and more about tactical practices of black self-determination and racial resiliency.

\section{Conclusion}

Black men as raced and gendered bodies understand manhood and perform masculinity in complex ways. The findings in this study make this evident and provide insight into black fatherhood, manhood and masculinity. The findings reveal similarities and points of departure with the literature on black manhood. In some ways, the sons and fathers held traditional and Victorian notions of manhood such as responsibility, providership and spirituality (Summers 2004).

However, race and gender intersect for these men in ways that elicit particular racialized male role performances and socialization practices. To respond to encounters 
with structural racism, the men attempted to construct manhood outside of hegemonic discourse and perform masculinities in opposition to dominant ideology on black males. Their simultaneous awareness of dominant views of black masculinity and their attempt to self-define reflects a modern experience of Dubois' (1903) notion of double consciousness, where black men must negotiate tensions between how the white world sees them and how they attempt to see themselves.

As acts of racial resiliency, the men performed masculinities that were critical responses to an understanding of structural barriers, but were tactically enacted within specific contexts. Furthermore, as masculinity is modeled and learned, the proactive racial socialization practices of the fathers provide rare insight into the parental practices of black residential fathers and the construction of black manhood.

Finally, the findings contribute to the anti-deficit discourses on black men (Harper 2012; Wright 2011; Hrabowski III, Maton, and Greif 1998), highlighting progressive masculinities that contest dominant expectations of black manhood and masculinities. Most notable, is the presence of these black fathers in their children's lives and their ability to model masculinities to their sons. Future research should continue an examination of black fathers, their socializing practices and their complex understandings of manhood and masculinity. 


\section{References}

Anderson, Elijah. 1990. Code of the Street: Decency, violence, and the moral life of the inner city. New York: W.W. Norton \& Co. .

Anderson, Eric. 2002. "Openly Gay Athletes: Contesting hegemonic masculinity in a homophobic environment." Gender and Society 16 (6):860 - 77.

Author. 2013. "Details withheld for peer review."

Bandura, A., and R.H. Walters. 1963. Social learning and personality development. New York: Holt, Rinehart and Winston.

Brittan, Arthur. 1989. Masculinity and Power. Oxford: Blackwell.

Bureau, Census. 2008. "Poverty Thresholds for 2008 by Size of Family and Number of Related Children under 18 Years." In.: U.S. Census Bureau.

Butler, Judith. 1993. Bodies that Matter. London: Routledge.

Caldwell, Cleopatra Howard, Robert M. Sellers, Debra Hilkene Bernat, and Marc A. Zimmerman. 2004. "Racial identity, parental support, and alcohol use in a sample of academically at-risk African American high school students." American Journal of Community Psychology (1-2):71.

Carter, Prudence. 2006. "Straddling boundaries: Identity, culture, and school." Sociology of Education 79 (4):304-28.

Caughy, Margaret O'Brien, Patricia J. O'Campo, Suzanne M. Randolph, and Kim Nickerson. 2002. "The Influence of Racial Socialization Practices on the Cognitive and Behavioral Competence of African American Preschoolers." Child Development 73 (5):1611 - 25.

Chien-Chung Huang. 2002. "The Impact of Child Support Enforcement on Nonmarital and Marital Births: Does It Differ by Racial and Age Groups?" Social Service Review 76 (2):275-301. doi: 10.1086/339666.

Clayton, Obie, and Joan W. Moore. 2003. "The effects of crime and imprisonment on family formation." In Black fathers in contemporary American society : strengths, weaknesses, and strategies for change / Obie Clayton, Ronald B. Mincy, David Blankenhorn, editors, edited by Obie Clayton, Ronald B. Mincy and David Blankenhorn. New York : Russell Sage Foundation, c2003.

Coles, Roberta L. 2001. "The Parenting Roles and Goals of Single Black Full-Time Fathers." Western Journal of Black Studies 25 (2):101.

Collins, Sharon M. 1983. "The Making of the Black Middle Class." Social Problems 30 (4):369-82. 
Connell, Robert W. 1995. Masculinities. Oxford, UK: Polity Press.

Crenshaw, Kimberle, Neil Gotanda, Gary Peller, and Kendal Thomas. 1995. "Critical Race Theory: The key writings that formed the movement." In. New York: The New Press.

Dancy II, T. Elon E. 2012. The brother code: Manhood and masculinity among African American males in college. Charlotte, NC: Information Age Publishing.

Delgado-Gaitan, Concha, and Henry T. Trueba. 1991. Crossing cultural borders : education for immigrant families in America. London; New York: Falmer Press.

DuBois, W.E.B. 1903. The Souls of Black Folk. Chicago: A.C. McClurg and Co.

Dubowitz, Howard, Maureen M. Black, Christine E. Cox, Mia A. Kerr, Alan J. Litrownik, Aruna Radhakrishna, Diana J. English, Mary Wood Schneider, and Desmond K. Runyan. 2001. "Father Involvement and Children's Functioning at Age 6 Years: A Multisite Study." Child Maltreatment 6 (4):300.

Edin, Kathryn, and Timothy Jon Nelson. 2013. Doing the Best I Can : Fatherhood in the Inner City. Berkeley: University of California Press.

Fiske, Susan T., Hilary B. Bergsieker, Ann Marie Russell, and Lyle Williams. 2009. "Images of Black Americans." Du Bois Review: Social Science Research on Race 6 (01):83-101. doi: doi:10.1017/S1742058X0909002X.

Frazier, Edward F. 1966. The Negro Family in the United States. Chicago: The University of Chicago Press.

Gardiner, Judith Kegan. 2005. "Men, Masculinities, and Femist Theory." In Handbook of Studies on Men and Masculinities, edited by Michael S. Kimmel, Jeff Hearn and R.W. Connell, 35 - 50. Thousand Oaks, CA: Sage Publications.

Ginwright, Shawn A. 2002. "Classed Out: The challenges of social class in black community change." Social Problems 49 (4):544-62.

Goetz, J.P., and Margaret D. LeCompte. 1984. Ethnography and Qualitative Design in Educational Research. Orlando, FL: Academic Press, Inc.

Goffman, Erving. 1959. The Presentation of Self in Everyday Life. Garden City, N.Y.: Doubleday.

Gordon, Lewis R. 1997. Existence in Black : an anthology of Black existential philosophy / edited and with an introduction by Lewis R. Gordon: New York : Routledge, 1997.

Grantham, Tarek C., and Malik S. Henfield. 2011. "Black Father Involvement in Gifted Education: Thoughts from Black Fathers on Increasing/Improving Black FatherGifted Teacher Partnerships." Gifted Child Today 34 (4):47-53. 
Greif, Geoffrey L., Freeman A. Hrabowski, and Kenneth I. Maton. 1998. "African American fathers of high-achieving sons: Using outstanding members of an at-risk population to guide intervention." Families in Society 79 (1):45-.

Gutmann, Matthew C. 1997. "Trafficking in Men: The anthropology of masculinity." Annual Review of Anthropology 26:385 - 409.

Hall, Stuart, Charles Critcher, Tony Jefferson, John Clarke, and Brian Robert. 1978. Policing the Crisis: Mugging, the state and law and order. London: Macmillan.

Hamer, Jennifer F. 1997. "The fathers of "fatherless" black children." Families in Society 78 (6):564-78.

Harper, Shaun R. 2012. "Black male student success in higher education: A report from the national Black male college achievement study." In. Philadelphia: University of Pennsylvania, Center for the Study of Race and Equity in Education.

Harris, Angela P. 2000. "Gender, Violence, Race, and Criminal Justice." In, 777. Stanford University School of Law.

Harris, Keith M. 2006. Boys, Boyz, Bois: An Ethics of Black Masculinity in Film and Popular Media. Edited by Graham Hodges, Studies in African American History and Culture. New York \& London: Routledge.

Hebert, Thomas P., Alexander R. Pagnani, and Daniel R. Hammond. 2009. "An Examination of Paternal Influence on High-Achieving Gifted Males." Journal for the Education of the Gifted 33 (2):241-74.

Hoffman, Kathryn, Charmaine Llagas, and Thomas D. Snyder. 2003. "Status and trends in the education of Blacks." In. Washington, D.C.: US Department of Education, National Center for Educational Statistics.

Holter, Øystein Gullvåg 2005. "Social Theories for Researching Men and Masculinities: Direct gender hierarchy and structural inequality." In Handbook of Studies on Men and Masculinities, edited by Michael S. Kimmel, Jeff Hearn and R.W. Connell, 15 34. Thousand Oaks, CA: Sage Publications.

hooks, bell. 2003. We Real Cool: Black Men and Masculinity. New York: Routledge.

Hrabowski III, Freeman A., Kenneth I. Maton, and Geoffrey L. Greif. 1998. Beating the Odds: Raising academically successful African American males. New York: Oxford University Press.

Huberman, A. Michael, and Mattew B. Miles. 1994. "Data Management and Analysis Methods." In Handbook of Qualitative Research, edited by Norman Denzin and Yvonne Lincoln, 428-44. Sage Publications, Inc. 
Hunter, Andrea, and James Earl Davis. 1992. "Constructing Gender: An exploration of Afro-American men's conceptualization of manhood." Gender and Society 6 (3):464-79.

. 1994. "Hidden voices of black men: The meaning, structure, and complexity of manhood." Journal of Black Studies 25 (1):20-40.

Johnson Jr., Waldo E. 2001. "Young unwed African American fathers: Indicators of their pater- nal involvement." In Forging links : African American children clinical developmental perspectives / edited by Angela M. Neal-Barnett, Josefina M. Contreras, and Kathryn A. Kerns ; foreword by Bertha Garrett Holliday, edited by Angela M. Neal-Barnett, Josefina M. Contreras and Kathryn A. Kerns. Westport, Conn. : Praeger, 2001.

Lacy, Karyn R. 2007. Blue-Chip Black: Race, class, and status in the new black middle class. Berkeley and Los Angeles, CA: University of California Press.

Lamb, Michael E. 2004. The role of the father in child development / edited by Michael E. Lamb: Hoboken, N.J. : Wiley, c2004.

4th ed.

Lamont, Mich, egrave, le, and Crystal Marie Fleming. 2005. "EVERYDAY ANTIRACISM: Competence and Religion in the Cultural Repertoire of the African American Elite." Du Bois Review: Social Science Research on Race 2 (01):29-43. doi: doi:10.1017/S1742058X05050046.

Mac an Ghaill, Mairtin. 1994. The Making of Men: Masculinities, sexualities and schooling. Buckingham: Open University Press.

Mandara, Jelani. 2006. "The Impact of Family Functioning on African American Males' Academic Achievement: A Review and Clarification of the Emperical Literature." Teachers College Record 108 (2):206 - 23.

Marriott, David. 1996. "Reading Black Masculinities." In Understanding Masculinities, edited by Mairtin Mac an Ghaill, 185 - 201. Buckingham: Open University.

Mauer, Marc. 1999. "Crisis of the Young African American Male and the Criminal Justice System." In, 43 - 55. Washington, D.C.: The Sentencing Project.

McLoyd, Vonnie C., Ana Mari Cauce, and David Takeuchi. 2000. "Marital processes and parental socialization in families of color: a decade review of research." Journal of Marriage \& Family 62 (4):1070-93. doi: 10.1111/j.1741-3737.2000.01070.x.

Moynihan, Daniel P. 1965. The Negro Family: The case for national action. Washington, DC: US Department of Labor.

Mustard, David B. 2001. "Racial, Ethnic, and Gender Disparities in Sentencing: Evidence from the U.S. Federal Courts." The Journal of Law and Economics 44 (1):285 - 314. 
Nunez-Smith, Marcella, Leslie Curry, A., JudyAnn Bigby, David Berg, Harlan Krumholz, and Elizabeth Bradley, H. 2007. "Impact of Race on the Professional Lives of Physicians of African Descent." Annals of Internal Medicine 146 (1):45-52.

Pan, E., and M. P. Farrel. 2006. "Ethnic differences in the effects of intergenerational relations on adolescent problem behavior in U.S. single-mother families." Journal of Family Issues 27 (8):1137-58.

Pattillo-McCoy, Mary. 1999. Black Picket Fences: Privilege and peril among the black middle class. Chicago: The University of Chicago Press.

Pierce, C., J. Carew, D. Peirce-Gonzalez, and D. Willis. 1978. "An experiment in racism: TV commercials." In Television and Education, edited by C. Pierce, 62-88. Beverly Hills: Sage.

Pleck, Joseph H. 1981. The myth of masculinity. Cambridge, MA: MIT Press.

Rollock, Nicola, David Gillborn, Carol Vincent, and Stephen Ball. 2011. "The public identities of the Black middle classes: Managing race in public spaces." Sociology 45 (6): 1078-93.

Shattuck, Rachel M., and Rose M. Kreider. 2013. "Social and econommic characteristics of currently unmarried women with a recent birth: 2011." In, edited by U.S. Department of Commerce. U.S. Census Bureau.

Smith, William A. 2004. "Black faculty coping with racial battle fatigue: The campus climate in a post-civil rights era." In A long way to go: Conversations about race by African American faculty and graduate students, edited by Darrell Cleveland. New York: Peter Lang.

Staples, Robert. 1982. Black Masculinity: The black male's role in American society. San Francisco: The Black Scholar Press.

Summers, Martin. 2004. Manliness and its Discontents: The Black Middle Class and the Transformation of Masculinity, 1900 - 1930. Chapel Hill and London: The University of North Carolina Press.

Taylor, R. 2002. Minority families in the United States: A multicultural perspective. 3 ed. Upper Saddle River, NJ: Prentice Hall.

U.S. Department of Justice. 2012. "Prison and jail inmates at midyear." In, edited by Bureau of Justice Statistics. Washington, DC: Bureau of Justice Statistics.

U.S. Department of Labor. 2013. "Employment situation." In. Washington, DC: Bureau of Labor Statistics.

Watkins, W. . 1993. "Black curriculum orientations: A preliminary inquiry." Harvard Educational Review 63 (3):321-8. 
Welburn, Jessica S., and Cassi L. Pittman. 2011. "Stop ,'blaming the man': perceptions of inequality and opportunities for success in the Obama era among middle-class African Americans." Ethnic and Racial Studies 35 (3):523-40. doi: 10.1080/01419870.2011.589907.

Wheary, Jennifer, Thomas Shapiro, Tamara Draut, and Tatjana Meschede. 2008. "Economic (in)security: The experience of the African-American and Latino middle classes." In. New York, NY: Institute on Assets \& Social Policy.

Whitehead, Stephen M., and Frank Barrett. 2001. "The Sociology of Masculinity." In The Masculinities Reader, edited by Stephen M. Whitehead and Frank Barrett, 1 - 26. Cambridge, England: Polity Press.

Wilkinson, Zuline G. 1999. "Crisis of African American Male: Barriers to Successful Employment." In The Crisis of the Young African American Male in the Inner Cities, 185 - 91. Washington, D.C.: A Consultation of the United States Commission on Civil Rights.

Wright, Brian L. 2011. "I know who I am, do you? Identity and academic achievement of successful African American male adolescents in an urban pilot high school in the United States." Urban Education 46 (4):611-38.

Yosso, Tara J. 2006. "Whose Culture Has Capital? A critical race theory discussion of community cultural wealth." In Critical Race Theoy in Education: All God's Children Got a Song, edited by Adrienne D. Dixson and Celia K. Rousseau, 167-89. New York: Routledge. 
Table 1

Descriptors of Sons and Fathers

\begin{tabular}{llll}
\hline \multicolumn{1}{c}{ Sons } & \multicolumn{1}{c}{ Fathers } & \multicolumn{1}{c}{ Occupation } & \multicolumn{1}{c}{ Education } \\
\hline Jamal Baker & Mr. Baker & Head Chef & Associates Degree \\
Sean Strauss & Mr. Strauss & Union Representative & Bachelors Degree \\
Billy Anderson & Mr. Anderson & Restaurant Manager & Bachelors Degree \\
Mark Thomas & Mr. Thomas & IT Manager & Bachelors Degree \\
Jayson Mensah & Mr. Mensah & Equipment Operator & H.S. Diploma \\
Rodney Howard & Mr. Howard & Parole Agent & Bachelors Degree \\
\hline
\end{tabular}

Quaylan Allen is Assistant Professor in the College of Educational Studies at Chapman University.

Address: Chapman University, One University Drive, Orange, CA 92866, US. Email:

qallen@chapman.edu 